\title{
Protection in Surinam
}

HARPY EAGLE

J. P. Schultz

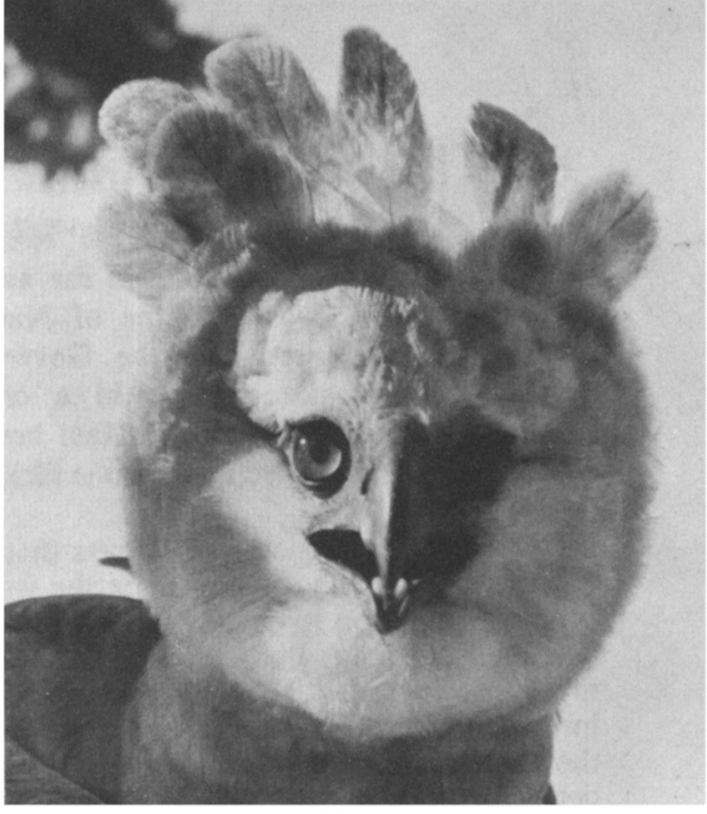

A well illustrated account by J. P. Schultz, of the Surinam Forest Service, of the country's nature parks and reserves-eight in action and one proposed-is published by the Netherlands Commission for International Nature Protection in Mededelingen No 20, from which this harpy eagle, one of Surinam's more dramatic birds, is reproduced. It includes an account of the efforts being made by the Foundation for Nature Preservation in Surinam, a semi-governmental organisation established in 1969, to conserve the warana, the olive ridley turtle Lepidochelys olivacea, which nests in huge numbers - up to 500 a night in June and July-on the $\frac{1}{2}-\mathrm{km}$-wide Eilanti beach in the Galibi nature reserve at the mouth of the Marowijne River. Until 1966 the local Indians made a 100 per cent clearance of the eggs, but for the next two years, with help from WWF, 80 per cent were bought from the Indians, and again in 1970 one-third were bought (there were no funds in 1969 and all were taken). These were allowed to hatch and the beach regularly patrolled. By leaving some eggs for the Indians it is hoped of course to get their cooperation and at the same time allow the turtles to increase. Scientific studies and tagging of turtles are going on at the same time.

\section{National Parks Awards}

Special awards made at the National Parks Conference included five Leadership Awards and six International Awards: the former went to $\mathrm{Mr}$ J. B. Alvarez Jr, Philippines; Mr Zekai Bayer, Turkey; $\mathrm{Mr}$ Mario Boza, Costa Rica; Mr Perez Olindo, Kenya; and Mr Phariot Suvanakon, Thailand; the latter to Mr Enrique Beltran, Mexico; Mr Harold Coolidge, USA; Sir Frank Fraser Darling, UK; Prof. Jean-Paul Harroy, Belgium; Dr Tsuyoshi Tamura, Japan; Dr Jacques Verschuren, Zäire (Belgium).

\section{National Parks List}

An Addendum to the UN List of National Parks and Equivalent Resources (Hayez, Brussels, US \$5 post paid) brings this invaluable work up to June 30, 1972, and describes all areas added since 1970. 